Check for updates

Cite this: RSC Adv., 2020, 10, 7803

\title{
Arrangement of water molecules and high proton conductivity of tunnel structure phosphates, $\mathrm{KMg}_{1-x} \mathrm{H}_{2 x}\left(\mathrm{PO}_{3}\right)_{3} \cdot \mathrm{yH}_{2} \mathrm{O} \uparrow$
}

\begin{abstract}
Yasuaki Matsuda, (D) *a Kousei Funakoshi, ${ }^{a}$ Ryosuke Sebe, ${ }^{a}$ Genki Kobayashi, (DD ${ }^{b}$ Masao Yonemura, ${ }^{c}$ Nobuyuki Imanishi, ${ }^{d}$ Daisuke Mori (iD d and Shinya Higashimoto ${ }^{a}$

A fast proton conductor was investigated in a mixed-valence system of phosphates with a combination of large cations $\left(\mathrm{K}^{+}\right)$and small cations $\left(\mathrm{Mg}^{2+}\right)$, which resulted in a new phase with a tunnel structure suitable for proton conduction. $\mathrm{KMg}_{1-x} \mathrm{H}_{2 x}\left(\mathrm{PO}_{3}\right)_{3} \cdot y \mathrm{H}_{2} \mathrm{O}$ was synthesized by a coprecipitation method. A solid solution formed in the range of $x=0-0.18$ in $\mathrm{KMg}_{1-x} \mathrm{H}_{2 x}\left(\mathrm{PO}_{3}\right)_{3} \cdot y \mathrm{H}_{2} \mathrm{O}$. The structure of the new proton conductor was determined using neutron and $X$-ray diffraction measurements. $\mathrm{KMg}_{1-x} \mathrm{H}_{2 x}\left(\mathrm{PO}_{3}\right)_{3} \cdot y \mathrm{H}_{2} \mathrm{O}$ has a tunnel framework composed of face-shared $\left(\mathrm{KO}_{6}\right)$ and $\left(\mathrm{MgO}_{6}\right)$ chains, and $\mathrm{PO}_{4}$ tetrahedral chains along the $c$-direction by corner-sharing. Two oxygen sites of water molecules were detected in the onedimensional tunnel, one of which exists as a coordination water of $\mathrm{K}^{+}$sites. Multi-step dehydration was observed at $30^{\circ} \mathrm{C}$ and $150{ }^{\circ} \mathrm{C}$ from thermogravimetric/differential thermal analysis measurements, which reflects the different coordination environments of the water of crystallization. Water molecules are connected to $\mathrm{PO}_{4}$ tetrahedra by hydrogen bonds and form a chain along the c-axis in the tunnel, which would provide an environment for fast proton conduction associated with water molecules. The $\mathrm{KMg}_{1-x} \mathrm{H}_{2 x}\left(\mathrm{PO}_{3}\right)_{3} \cdot y \mathrm{H}_{2} \mathrm{O}$ sample with $x=0.18$ exhibited high proton conductivity of $4.5 \times 10^{-3} \mathrm{~S} \mathrm{~cm}^{-1}$ at $150{ }^{\circ} \mathrm{C}$ and $7.0 \times 10^{-3} \mathrm{~S} \mathrm{~cm}^{-1}$ at $200{ }^{\circ} \mathrm{C}$ in a dry Ar gas flow and maintained the total conductivity above

$10^{-3} \mathrm{~S} \mathrm{~cm}^{-1}$ for $60 \mathrm{~h}$ at $150{ }^{\circ} \mathrm{C}$ under $\mathrm{N}_{2}$ gas atmosphere.
\end{abstract}

Received 22nd January 2020

Accepted 14th February 2020

DOI: $10.1039 /$ d0ra00690d

rsc.li/rsc-advances

\section{Introduction}

Proton conduction is an essential phenomenon common in the metabolism of biological systems ${ }^{1-3}$ and the operation of electrochemical devices such as fuel cells. ${ }^{4-9}$ An understanding of proton conduction and the development of fast proton conductors are important for material science, chemistry, and biology due to fundamental interests and potential applications. Fast proton conduction in solids has been achieved by the design of proton conduction pathways in their crystal structures. The discovery and structural investigation of new proton conductors provide deep insights into the origin of fast proton conduction in solids and a means to design better proton conductors. Studies based on representative proton

\footnotetext{
${ }^{a}$ Department of Applied Chemistry, Faculty of Engineering, Osaka Institute of Technology, 5-16-1 Ohmiya, Asahi-Ku, Osaka, 535-8585, Japan. E-mail: yasuaki. matsuda@oit.ac.jp

${ }^{b}$ Research Center of Integrative Molecular Systems (CIMoS), Institute for Molecular Science, 38 Nishigonaka, Myodaiji, Okazaki, Aichi 444-8585, Japan

'Institute of Materials Structure Science, High Energy Accelerator Research Organization, 1-1 Oho, Tsukuba, Ibaraki 305-0801, Japan

${ }^{d}$ Department of Chemistry for Materials, Graduate School of Engineering, Mie University, 1577 Kurimamachiya-cho, Tsu, Mie 514-8507, Japan

$\dagger$ Electronic supplementary information (ESI) available. See DOI: 10.1039/d0ra00690d
}

conductors $^{10-16}$ have promoted the development of fuel cell electrolyte materials. ${ }^{7-9}$ Incombustible inorganic solids have a potential to extend the operation temperature of proton solid electrolytes, however the design of materials that exhibit high proton conductivity and thermal stability is still a big challenge because of the difficulty controlling hydrogen bonds in the solids.

Since the framework formed by hydrogen bonds is difficult to improve thermal stability, we have investigated materials that have a fast proton diffusion pathway in the rigid framework formed by covalent and ionic bonds. Among the inorganic solids, we have focused on mixed-valence systems of phosphates because they tend to form open frameworks by the connection of $\mathrm{PO}_{4}$ tetrahedra. Furthermore, mixed-valence systems may introduce excess protons into the structure by changing the cation molar ratio, and these protons form hydrogen bonds with $\mathrm{PO}_{4}$ tetrahedra. These protons result in changes to the hydrogen bond network that is suitable for fast proton conduction in the host structure. Based on this concept, we have discovered a tunnel phosphate, $\mathrm{RbMg}_{1-x} \mathrm{H}_{2 x}\left(\mathrm{PO}_{3}\right)_{3}$ $\cdot y \mathrm{H}_{2} \mathrm{O}$, which exhibits high proton conductivity above $10^{-3} \mathrm{~S} \mathrm{~cm} \mathrm{~cm}^{-1}$ over a wide temperature range from room temperature to $250{ }^{\circ} \mathrm{C} .{ }^{17}$ The framework of $\mathrm{RbMg}_{1-x} \mathrm{H}_{2 x}\left(\mathrm{PO}_{3}\right)_{3}$ $\cdot y \mathrm{H}_{2} \mathrm{O}$ is composed of the corner-sharing of face-shared $\left(\mathrm{RbO}_{6}\right)$ and $\left(\mathrm{MgO}_{6}\right)$ chains and corner-shared $\mathrm{PO}_{4}$ tetrahedral chains. 
Excess protons introduced by the introduction of vacancies at $\mathrm{Mg}^{2+}$ sites induce hydrophilic head groups $\left(-\mathrm{PO}_{4} \mathrm{H}\right)$ into the $\mathrm{PO}_{4}$ framework, which act as binding sites for water molecules. Therefore, water molecules are distributed adjacent to each other and form chains along the $\mathrm{PO}_{4}$ tetrahedral chains in the one-dimensional tunnel. This provides an environment for fast proton diffusion, which is similar to the proton channels observed in biological systems. ${ }^{17}$

The tunnel phosphate is attractive as a proton solid electrolyte if it can be synthesized with inexpensive elements and maintain high proton conductivity over $10^{-3} \mathrm{~S} \mathrm{~cm}^{-1}$ above $100{ }^{\circ} \mathrm{C}$ at which most of proton conductors containing water molecules become unstable. However, the relationship between crystal structure and the combination of constitute cations in the water containing phosphates with alkali and alkaline earth cations have not been clarified yet. Therefore, except for $\mathrm{RbMg}_{1-x} \mathrm{H}_{2 x}\left(\mathrm{PO}_{3}\right)_{3} \cdot y \mathrm{H}_{2} \mathrm{O}$, proton conductors with the water chain in the tunnel framework haven't been discovered. To obtain new proton conductor, we attempted to synthesize a new tunnel phosphate combining $\mathrm{Mg}^{2+}$ and $\mathrm{K}^{+}$by a coprecipitation method that is suitable for low-temperature synthesis. The replacement of $\mathrm{Rb}^{+}$for a smaller alkali cation of $\mathrm{K}^{+}$would cause shrinkage of the tunnel framework. We expected the improvement of the proton conductivity by decreasing the distance between water molecules in the tunnel due to lattice contraction. To understand the relationship between the arrangement of water molecules and proton conductivity, the crystal structure of the new proton conductor was determined using neutron and X-ray diffraction (XRD) measurements. Excess protons were introduced by vacancies at $\mathrm{Mg}^{2+}$ sites to improve proton conductivity. In present study, the synthesis, crystal structure and proton conductivity of $\mathrm{KMg}_{1-x} \mathrm{H}_{2 x}\left(\mathrm{PO}_{3}\right)_{3} \cdot y \mathrm{H}_{2} \mathrm{O}$ are discussed.

\section{Experimental}

The $\mathrm{KMg}_{1-x} \mathrm{H}_{2 x}\left(\mathrm{PO}_{3}\right)_{3} \cdot y \mathrm{H}_{2} \mathrm{O}$ series was synthesized by a coprecipitation method. Appropriate molar ratios of $\mathrm{K}_{2} \mathrm{CO}_{3}$ (Nacalai Tesque, $>99.5 \%)$ and $\left(\mathrm{MgCO}_{3}\right)_{4} \mathrm{Mg}(\mathrm{OH})_{2} \cdot x \mathrm{H}_{2} \mathrm{O}$ (Nacalai Tesque) were weighed and dissolved in $30 \mathrm{~mL}$ of phosphoric acid solution ( $0.5 \mathrm{~mol} \mathrm{~L}^{-1}$, Kanto Chemical Lab. Co.). To compensate for the compositional deviation of the starting materials, a $2 \mathrm{~mol} \%$ excess of potassium was added. The solution was heated at $120{ }^{\circ} \mathrm{C}$ in air for several days and a white colored residual powder was obtained. The sample powder obtained was pressed into a pellet (10 $\mathrm{mm}$ diameter, $1-2 \mathrm{~mm}$ thick) and then heated in air at $250{ }^{\circ} \mathrm{C}$ for $12-24 \mathrm{~h}$ on a polytetrafluoroethylene (PTFE) sheet in a watch glass with an intermediate grinding step. XRD patterns of the powder samples were obtained using a diffractometer (Rigaku RINT2000) with $\mathrm{Cu} \mathrm{K} \alpha$ radiation in the $2 \theta$ range from 10 to $90^{\circ}$ at $0.02^{\circ}$ step widths. Thermogravimetry/ differential thermal analysis (TG/DTA; Rigaku Thermo Plus EVO TG 8120) were performed at a heating rate of $5^{\circ} \mathrm{C} \mathrm{min}^{-1}$ in a $\mathrm{N}_{2}$ gas flow. The structures of the samples were refined by $\mathrm{X}$ ray Rietveld analysis using the RIETAN-FP program. ${ }^{18}$ Neutron diffraction (ND) data were collected using a time-of-flight (TOF) neutron powder diffractometer (SPICA at J-PARC, Japan).
Samples (ca. $1.0 \mathrm{~g})$ were placed in cylindrical vanadium cells (12 $\mathrm{mm}$ diameter, $55 \mathrm{~mm}$ height). The structural parameters were refined by Rietveld analysis using the Z-Rietveld program. ${ }^{19}$ The ionic conductivities were measured by the AC impedance method in the temperature range from room temperature to $250{ }^{\circ} \mathrm{C}$ in a dry Ar gas flow and under $\mathrm{N}_{2}$ gas atmosphere over the frequency range of $10 \mathrm{~Hz}$ to $1 \mathrm{MHz}$ using a frequency response analyzer (Bio-Logic VSP 300) and an LCR meter (Hioki MI3536). The moisture in the Ar gas was removed with a gas purifier to less than $0.03 \%$. Measurements were performed using a sample pellet $(10 \mathrm{~mm}$ diameter, 1-2 $\mathrm{mm}$ thick) with gold electrodes on each side. The relative density of the measured pellet was approximately $80 \%$.

\section{Results and discussion}

XRD patterns for $\mathrm{KMg}_{1-x} \mathrm{H}_{2 x}\left(\mathrm{PO}_{3}\right)_{3} \cdot y \mathrm{H}_{2} \mathrm{O}$ synthesized in air at $250{ }^{\circ} \mathrm{C}$ are shown in Fig. 1. The diffraction patterns for all samples are similar to that of $\operatorname{RbMg}\left(\mathrm{PO}_{3}\right)_{3} \cdot y \mathrm{H}_{2} \mathrm{O},{ }^{17}$ and the diffraction peaks were indexed to a rhombohedral unit cell. In contrast to $\mathrm{KMg}\left(\mathrm{PO}_{3}\right)_{3}$ with the layered structure reported previously, ${ }^{20}$ the new phase with a tunnel structure was most likely obtained due to the low temperature of synthesis by the coprecipitation method. Above the composition of $x=0.18$, crystalline samples were not obtained by heating at $250{ }^{\circ} \mathrm{C}$. The diffraction peaks of $\mathrm{KMg}_{1-x} \mathrm{H}_{2 x}\left(\mathrm{PO}_{3}\right)_{3} \cdot y \mathrm{H}_{2} \mathrm{O}$ were observed at higher $2 \theta$ angles than those of $\mathrm{RbMg}\left(\mathrm{PO}_{3}\right)_{3} \cdot y \mathrm{H}_{2} \mathrm{O}$, which is due to the replacement of $\mathrm{Rb}^{+}$with the smaller $\mathrm{K}^{+}$cation. The diffraction peaks tended to shift to higher angles with an increase in $x$, which indicates the formation of a solid solution.

Fig. 2 shows the change in the lattice parameter as a function of $x$ in $\mathrm{KMg}_{1-x} \mathrm{H}_{2 x}\left(\mathrm{PO}_{3}\right)_{3} \cdot y \mathrm{H}_{2} \mathrm{O}$. The lattice parameter $a$ remained constant, while $c$ decreased slightly from $x=0$ to 0.08 , after which both $a$ and $c$ decreased largely from $x=0.08$ to $x=0.18$. Several factors may affect the change in the lattice parameters of the solid solution, such as vacancies at $\mathrm{Mg}^{2+}$ sites, excess protons and the water of crystallization. A similar tendency was observed for $\mathrm{RbMg}_{1-x} \mathrm{H}_{2 x}\left(\mathrm{PO}_{3}\right)_{3} \mathrm{H}_{2} \mathrm{O} .{ }^{17}$

Fig. 3 shows TG/DTA curves for the sample with $x=0.18$ between 30 and $800{ }^{\circ} \mathrm{C}$. Water loss proceeded from $30^{\circ} \mathrm{C}$ and at

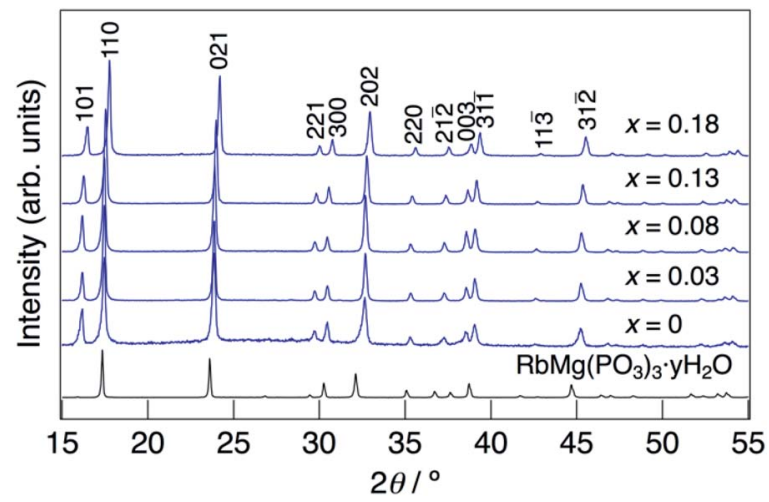

Fig. 1 XRD patterns for $\mathrm{KMg}_{1-x} \mathrm{H}_{2 x}\left(\mathrm{PO}_{3}\right)_{3} \cdot y \mathrm{H}_{2} \mathrm{O}$ synthesized in an air at $250{ }^{\circ} \mathrm{C}$ for $12 \mathrm{~h}$. 


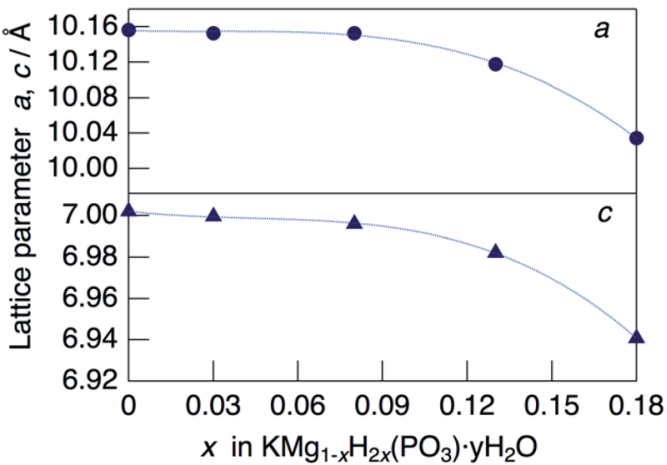

Fig. 2 Lattice parameters as a function of $x$ in $\mathrm{KMg}_{1-x} \mathrm{H}_{2 x}\left(\mathrm{PO}_{3}\right)_{3} \cdot y \mathrm{H}_{2} \mathrm{O}$.

$150^{\circ} \mathrm{C}$. At the initial step, a large weight loss was observed at 30$100{ }^{\circ} \mathrm{C}$, and then a small amount of water loss occurred at 100$150{ }^{\circ} \mathrm{C}$. It is considered that the initial step corresponds to the loss of adsorbed water and water of crystallization, and the second step corresponds to the loss of only water of crystallization. The water content calculated based on the occupancy values of oxygen of water molecules obtained by structural refinement mentioned later suggests the loss of water of crystallization is the predominant contributor to the weight loss at the initial step. It is expected that the weight loss at $30-100{ }^{\circ} \mathrm{C}$ includes a small amount of adsorbed water, however clear separation of weight loss corresponding to desorption of water of crystallization was difficult from the TG/DTA curves. The water contents of $\mathrm{KMg}_{1-x} \mathrm{H}_{2 x}\left(\mathrm{PO}_{3}\right)_{3} \cdot y \mathrm{H}_{2} \mathrm{O}$ with $x=0.18$ calculated from the weight loss in the range of $30-150{ }^{\circ} \mathrm{C}$ as the initial dehydration step, and that in $150-800{ }^{\circ} \mathrm{C}$ as the second step were $0.8 \mathrm{H}_{2} \mathrm{O}$ and $1.1 \mathrm{H}_{2} \mathrm{O}$ per unit formula.

The structure of $\mathrm{KMg}_{1-x} \mathrm{H}_{2 x}\left(\mathrm{PO}_{3}\right)_{3} \cdot y \mathrm{H}_{2} \mathrm{O}$ was determined by Rietveld refinement using XRD and ND data. Two structural models, $\mathrm{RbMg}\left(\mathrm{PO}_{3}\right)_{3} \cdot y \mathrm{H}_{2} \mathrm{O}$ : space group $R 32$ with $\mathrm{Mg}$ in $3 \mathrm{a}, \mathrm{K}$ in $3 \mathrm{~b}, \mathrm{P}$ in $9 \mathrm{e}, \mathrm{O}(1)$ in $18 \mathrm{f}, \mathrm{O}(2)$ in $9 \mathrm{~d}$ and $\mathrm{O}(3)$ in $18 \mathrm{f}$ sites, ${ }^{17}$ and $\mathrm{KNi}\left(\mathrm{PO}_{3}\right)_{3}$ : space group $R 3$ with $\mathrm{Mg}$ in $3 \mathrm{a}, \mathrm{K}$ in $3 \mathrm{a}, \mathrm{P}$ in $9 \mathrm{~b}, \mathrm{O}(1)$ in $9 \mathrm{~b}, \mathrm{O}(2)$ in $9 \mathrm{~b}$ and $\mathrm{O}(3)$ in $9 \mathrm{~b}$ sites $^{21}$ were examined as initial models for X-ray Rietveld refinement. The refinement based on the former model resulted in high values of the conventional agreement factors. The difference Fourier map showed residuals at $\mathrm{K}$ and $\mathrm{Mg}$ sites, which suggested the irrelevant atomic

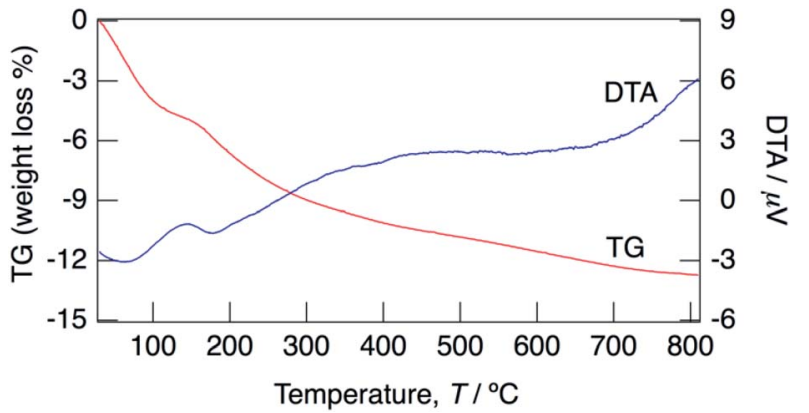

Fig. 3 TG/DTA curves for $\mathrm{KMg}_{1-x} \mathrm{H}_{2 x}\left(\mathrm{PO}_{3}\right)_{3} \cdot y \mathrm{H}_{2} \mathrm{O}$ with $x=0.18$ measured at a heating rate of $5^{\circ} \mathrm{C} \mathrm{min}^{-1}$ in a $\mathrm{N}_{2}$ gas flow. positions of these cations. Therefore, the refinement based on the latter model with low symmetry was examined to determine their atomic positions. As a result, reliability factors of $R_{\mathrm{wp}}=$ $8.31 \%, R_{\mathrm{p}}=6.40 \%, R_{\mathrm{e}}=5.17 \%, R_{\mathrm{B}}=3.81 \%$, and $R_{\mathrm{F}}=2.38 \%$ with refined lattice parameters of $a=10.1594(3) \AA$ and $c=$ 6.9986(2) A were obtained. Refinement provided an occupancy value of $0.824(5)$ for magnesium at the $3 \mathrm{a}$ site, which was consistent with the nominal composition. Two oxygen sites corresponding to the water of crystallization were newly determined. ND data were refined based on the result using the structural model with space group $R 3$. Proton sites assumed by the difference Fourier map were refined. The final XRD and ND Rietveld refinement patterns for $\mathrm{KMg}_{0.82} \mathrm{H}_{0.36}\left(\mathrm{PO}_{3}\right)_{3} \cdot 1.9 \mathrm{H}_{2} \mathrm{O}$ are shown in Fig. 4 and 5, respectively. The refined structural parameters are listed in Table 1, and the selected bond lengths and bond angles are summarized in Table $\mathrm{S} 1 . \dagger$

Fig. 6 shows the crystal structure of $\mathrm{KMg}_{0.82} \mathrm{H}_{0.36}\left(\mathrm{PO}_{3}\right)_{3}$ $\cdot 1.9 \mathrm{H}_{2} \mathrm{O}$ viewed along the [001] direction (a), the framework structure viewed along the [110] direction (b), and a onedimensional water chain with the local environment of water molecules located in the one-dimensional tunnel formed by $\mathrm{PO}_{4}$ tetrahedra (c). The $\mathrm{PO}_{4}$ tetrahedra are slightly distorted from the ideal tetrahedron; structural refinement results indicated that the $\mathrm{P}-\mathrm{O}$ bond lengths and $\mathrm{O}-\mathrm{P}-\mathrm{O}$ bond angles are varied in the ranges of 1.38-1.71 $\AA$ and $97.2-124^{\circ}$, which are slightly deviated from the sum of the ionic radii (1.55 $\AA$ ) and the ideal bond angle of a tetrahedron $\left(109.5^{\circ}\right)$. The $\mathrm{PO}_{4}$ tetrahedra are connected with each other by corner-sharing at $\mathrm{O}(1)$ to form chains along the $c$ axis direction. The bond lengths between $\mathrm{K}^{+}$and oxygen are varied at 2.78-2.88 $\AA$ and those between $\mathrm{Mg}^{2+}$ and oxygen are 2.04-2.10 $\AA$. $\mathrm{K}^{+}$is situated at the off-centered position at the octahedral sites. $\mathrm{KO}_{6}$ octahedra and $\mathrm{MgO}_{6}$ octahedra are ordered and form chains along the $c$-axis direction by face-sharing. These chains are connected with $\mathrm{PO}_{4}$ tetrahedra by corner-sharing at $\mathrm{O}(2)$ and $\mathrm{O}(3)$. Water molecules are located in the one-dimensional tunnel along $\mathrm{PO}_{4}$ tetrahedral chains in the $c$-axis direction.

Two oxygen, $\mathrm{O}(4)$ and $\mathrm{O}(5)$, and four hydrogen sites, $\mathrm{H}(1)$, $\mathrm{H}(2), \mathrm{H}(3)$ and $\mathrm{H}(4)$, exist in the one-dimensional tunnel and they form two water molecules of $\mathrm{H}(1)-\mathrm{O}(4)-\mathrm{H}(2)$ and $\mathrm{H}(3)-$ $\mathrm{O}(5)-\mathrm{H}(4)$. Bond distances and angles between the oxygen and proton sites are as follows: $\mathrm{O}(4)-\mathrm{H}(1): 0.28 \AA$; $\mathrm{O}(4)-\mathrm{H}(2): 0.60 \AA$; $\mathrm{O}(5)-\mathrm{H}(3): 0.57 \AA$ 品 $(5)-\mathrm{H}(4): 0.30 \AA$; $\mathrm{H}(1)-\mathrm{O}(4)-\mathrm{H}(2): 118^{\circ} ; \mathrm{H}(3)-$ $\mathrm{O}(5)-\mathrm{H}(4): 137^{\circ}$. These bond distances are comparable to the

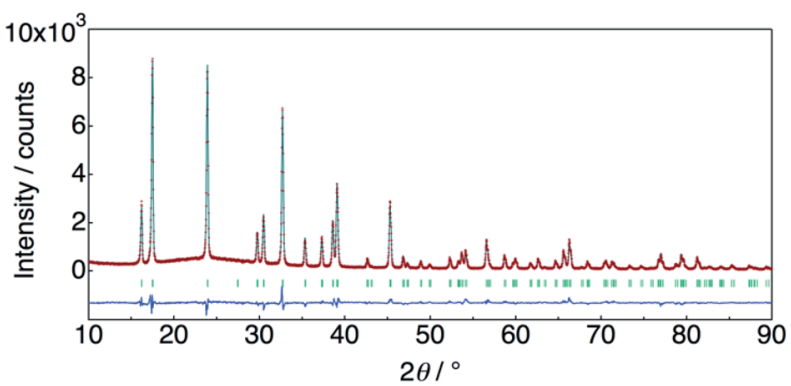

Fig. $4 \mathrm{X}$-ray Rietveld refinement pattern for $\mathrm{KMg}_{0.82} \mathrm{H}_{0.36}\left(\mathrm{PO}_{3}\right)_{3} \cdot 1.9 \mathrm{H}_{2} \mathrm{O}$. 


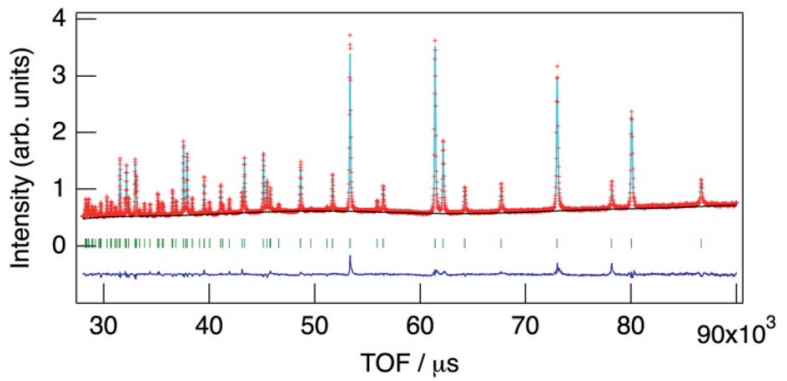

Fig. 5 Neutron Rietveld refinement pattern for $\mathrm{KMg}_{0.82} \mathrm{H}_{0.36}\left(\mathrm{PO}_{3}\right)_{3} \cdot 1.9 \mathrm{H}_{2} \mathrm{O}$

O-H bonds of water molecules $(<1.0 \AA)$, which suggests that these bonds correspond to the covalent bonds of water molecules. Bond angles of $118^{\circ}$ and $137^{\circ}$ for $\mathrm{H}(1)-\mathrm{O}(4)-\mathrm{H}(2)$ and $\mathrm{H}(3)-\mathrm{O}(5)-\mathrm{H}(4)$, respectively, are slightly distorted from the ideal bond angle of $105^{\circ}$ in $\mathrm{H}-\mathrm{O}-\mathrm{H}$ for a water molecule. The occupancy values of $\mathrm{O}(4)$ and $\mathrm{O}(5)$ are 0.22 and 0.34 , respectively. The sum of water content calculated from these occupancy values is $1.7 \mathrm{H}_{2} \mathrm{O}$ per unit formula, which is comparable to the value of $1.9 \mathrm{H}_{2} \mathrm{O}$ per unit formula calculated from the weight loss from 30 to $800{ }^{\circ} \mathrm{C}$ by TG/DTA measurement. The small difference between these may be due to desorption of adsorbed water during the initial weight loss step.

The water molecules are connected to $\mathrm{PO}_{4}$ tetrahedral chains through the hydrogen bonds. Both of the $\mathrm{H}(2)-\mathrm{O}(1)$ and $\mathrm{H}(3)-$ $\mathrm{O}(1)$ bonds with respective distances of 1.68 and $1.79 \AA$, which are considerably shorter than the hydrogen bond distances in water-contained materials, ${ }^{22,23}$ correspond to values between covalent bonding and hydrogen bonding. Large occupancy values of $\mathrm{H}(2)$ and $\mathrm{H}(3)$ suggest the coexistence of protons of water molecules and excess protons introduced by vacancies at $\mathrm{Mg}^{2+}$ sites. Intermediate $\mathrm{H}(2)-\mathrm{O}(1)$ and $\mathrm{H}(3)-\mathrm{O}(1)$ bond distances, and the slightly long covalent bonds of $\mathrm{O}(4)-\mathrm{H}(2)$ and $\mathrm{O}(5)-\mathrm{H}(3)$ may reflect the existence of excess protons between water molecules and the $\mathrm{PO}_{4}$ tetrahedral framework. Oxygen of

\begin{tabular}{lllllll}
\hline $\begin{array}{l}\text { Table } \\
\mathrm{KMg}_{0.82} \mathrm{H}_{0.36}\left(\mathrm{PO}_{3}\right)_{3} \cdot 1.9 \mathrm{H}_{2} \mathrm{O}^{a}\end{array}$ & \multicolumn{2}{l}{ structural } & \multicolumn{1}{l}{ parameters } & for \\
\hline Atom & Site & $g$ & $x$ & $y$ & $z$ & $B / \AA^{2}$ \\
\hline $\mathrm{K}$ & $3 \mathrm{a}$ & 1.0 & 0 & 0 & $0.4907(5)$ & 0.5 \\
$\mathrm{Mg}$ & $3 \mathrm{a}$ & 0.824 & 0 & 0 & 0 & 0.5 \\
$\mathrm{P}$ & $9 \mathrm{~b}$ & 1.0 & $0.013(10)$ & $0.5681(10)$ & $0.4648(4)$ & 0.5 \\
$\mathrm{O}(1)$ & $9 \mathrm{~b}$ & 1.0 & $0.0228(10)$ & $0.6344(10)$ & $0.2547(4)$ & 1.0 \\
$\mathrm{O}(2)$ & $9 \mathrm{~b}$ & 1.0 & $0.0827(10)$ & $0.1915(13)$ & $0.8234(4)$ & 1.0 \\
$\mathrm{O}(3)$ & $9 \mathrm{~b}$ & 1.0 & $0.1866(10)$ & $0.1058(10)$ & $0.1716(4)$ & 1.0 \\
$\mathrm{O}(4)$ & $9 \mathrm{~b}$ & $0.219(2)$ & $0.4039(4)$ & $-0.005(3)$ & $0.1880(5)$ & 1.2 \\
$\mathrm{O}(5)$ & $9 \mathrm{~b}$ & $0.336(3)$ & $0.5062(3)$ & $0.5903(3)$ & $0.0056(5)$ & 1.2 \\
$\mathrm{H}(1)$ & $9 \mathrm{~b}$ & $0.238(4)$ & $0.0552(11)$ & $0.3219(9)$ & $0.6138(12)$ & 1.6 \\
$\mathrm{H}(2)$ & $9 \mathrm{~b}$ & $0.372(3)$ & $0.4705(8)$ & $0.0171(6)$ & $0.2468(8)$ & 1.6 \\
$\mathrm{H}(3)$ & $9 \mathrm{~b}$ & $0.355(4)$ & $0.4901(7)$ & $0.5350(6)$ & $0.0932(8)$ & 1.6 \\
$\mathrm{H}(4)$ & $9 \mathrm{~b}$ & $0.190(4)$ & $0.5138(2)$ & $0.6021(13)$ & $0.014(17)$ & 1.6
\end{tabular}

${ }^{a}$ Space group: $R 3$ (146), $a=10.1726(10) \AA, c=7.008(10) \AA, S^{2}: 7.12, R_{\mathrm{wp}}$ (\%): $2.48, R_{\mathrm{p}}(\%): 1.84, R_{\mathrm{e}}(\%): 0.93, R_{\mathrm{B}}(\%): 4.73, R_{\mathrm{F}}(\%): 2.66$.
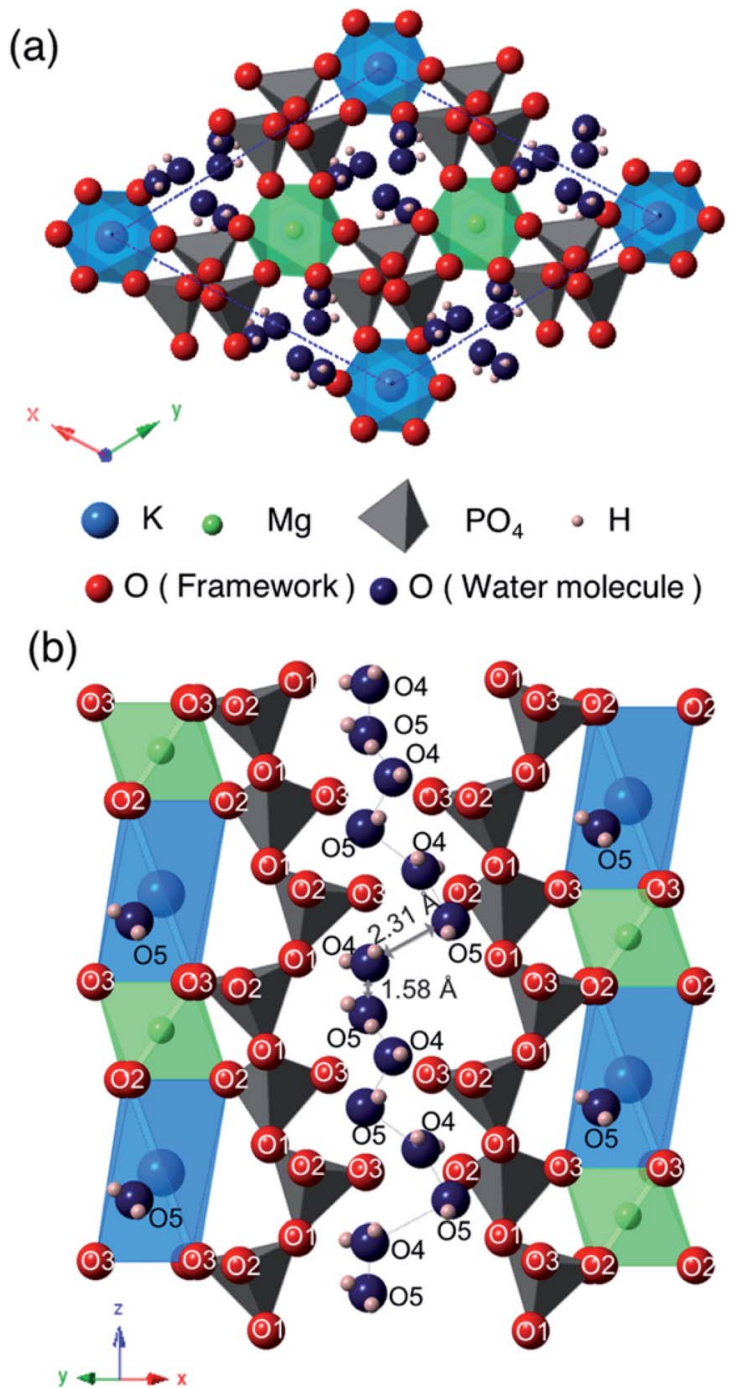

(c)

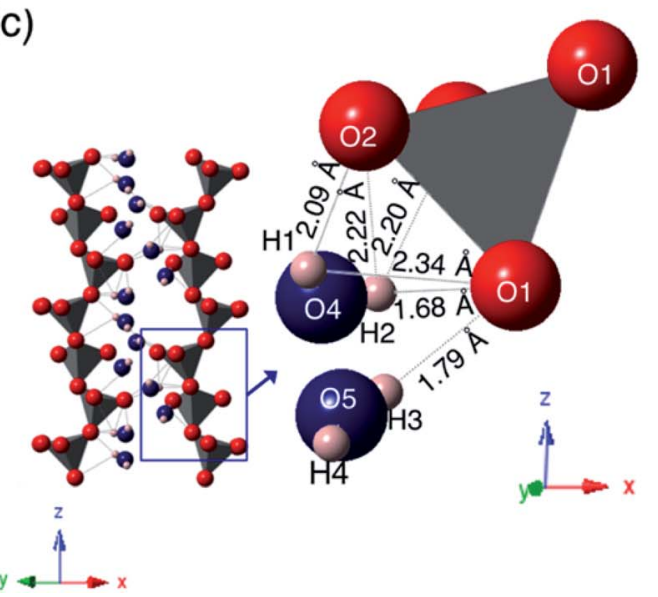

Fig. 6 Crystal structure of $\mathrm{KMg}_{0.82} \mathrm{H}_{0.36}\left(\mathrm{PO}_{3}\right)_{3} \cdot 1.9 \mathrm{H}_{2} \mathrm{O}$ viewed along the [001] direction (a), framework structure viewed along [110] direction (b), and one-dimensional water chain and the local environment of water molecules located in the one-dimensional tunnel formed by $\mathrm{PO}_{4}$ tetrahedral chains (c).

water molecules in the tunnel are located at sites near to $\mathrm{KO}_{6}$ octahedra, which may be due to the preference of large cations for a large coordination number of anions. 
The distances of $\mathrm{K}-\mathrm{O}(4)$ and $\mathrm{K}-\mathrm{O}(5)$ are $3.11 \AA$ and $2.36 \AA$, respectively. The short $\mathrm{K}-\mathrm{O}(5)$ distance indicates that $\mathrm{O}(5)$ and $\mathrm{K}$ are tightly connected and $\mathrm{O}(5)$ must be an oxygen of the coordination water of $\mathrm{K}$. The water content calculated from the occupancy value of $\mathrm{O}(4)$ is almost the same as that calculated from the weight loss at the initial step in the TG curve, and that calculated from the occupancy value of $\mathrm{O}(5)$ is in good agreement with that calculated from the weight loss at the second dehydration step. The multi-step dehydration observed by thermal measurement is thus due to the different coordination environments of water molecules.

Two water molecules are ordered along the $\mathrm{PO}_{4}$ tetrahedral chains in the one-dimensional tunnel and form chains in the $c$ direction. Adjacent water molecules are situated in the short distance of $1.58 \AA$ and $2.31 \AA$ for $\mathrm{O}(4)-\mathrm{O}(5)$, which is too short for oxygen to occupy these sites simultaneously. These two oxygen sites are thus partially occupied with occupation parameters of 0.22 and 0.34 , respectively, which are reasonable when considering the partial distribution of water molecules over these sites.

Fig. 7 shows impedance plots for $\mathrm{KMg}_{1-x} \mathrm{H}_{2 x}\left(\mathrm{PO}_{3}\right)_{3} \cdot y \mathrm{H}_{2} \mathrm{O}$ with $x=0-0.08$ (a) and $x=0.08-0.18$ (b) measured at $150{ }^{\circ} \mathrm{C}$ under $\mathrm{N}_{2}$ gas atmosphere in the closed cell. Fig. 8 shows variation of total conductivity as a function of $x$ in $\mathrm{KMg}_{1-x} \mathrm{H}_{2 x}(-$ $\left.\mathrm{PO}_{3}\right)_{3} \cdot y \mathrm{H}_{2} \mathrm{O}$ (a), and time dependence of the total conductivity of the sample with $x=0.18$ (b) measured at $150{ }^{\circ} \mathrm{C}$ under $\mathrm{N}_{2}$ gas atmosphere in the closed cell. The vapor pressure in the cell should be saturated considering the amount of dehydration observed in the TG curve and the volume of the space in the cell. The impedance plots measured at $150{ }^{\circ} \mathrm{C}$ showed a part of semicircle due to the grain boundary and a spike due to the electrode contribution. The total resistivity was obtained from the real axis intercepts of the semicircle corresponding to the grain boundary at the low frequency side. The total conductivity increased with increasing $x$ in $\mathrm{KMg}_{1-x} \mathrm{H}_{2 x}\left(\mathrm{PO}_{3}\right)_{3} \cdot y \mathrm{H}_{2} \mathrm{O}$. The introduction of excess protons enhances proton conductivity.

The sample with $x=0.18$ maintained a high total conductivity above $10^{-3} \mathrm{~S} \mathrm{~cm}^{-1}$ at $150{ }^{\circ} \mathrm{C}$ and exhibited the total conductivity of $2.4 \times 10^{-3} \mathrm{~S} \mathrm{~cm}^{-1}$ at $60 \mathrm{~h}$. This material maintains high-ionic conductivity in the measurement atmosphere in which water of crystallization is retained.

Fig. 9 shows impedance plots for $\mathrm{KMg}_{1-x} \mathrm{H}_{2 x}\left(\mathrm{PO}_{3}\right)_{3} \cdot y \mathrm{H}_{2} \mathrm{O}$ with $x=0.18$ measured under dry Ar gas flow at $25-125^{\circ} \mathrm{C}$ (a), and expansion of the high frequency part (b). At $25^{\circ} \mathrm{C}$, a part of the semicircle corresponding to the bulk and a large semicircle due to the grain boundary were observed. At $52{ }^{\circ} \mathrm{C}$, an end part of the semicircle due to the bulk and a second semicircle due to the grain boundary were observed in the high frequency range, while a spike due to the electrode contribution in the lowfrequency range.

Above $52{ }^{\circ} \mathrm{C}$, a semicircle due to the grain boundary and a spike due to the electrode contribution were observed. The bulk resistivity was obtained from the real axis intercepts of the semicircle corresponding to the grain boundary at the high frequency side. The total resistivity was obtained from the real axis intercepts of the spike corresponding to the electrode contribution. A comparison of the ionic conductivity of the
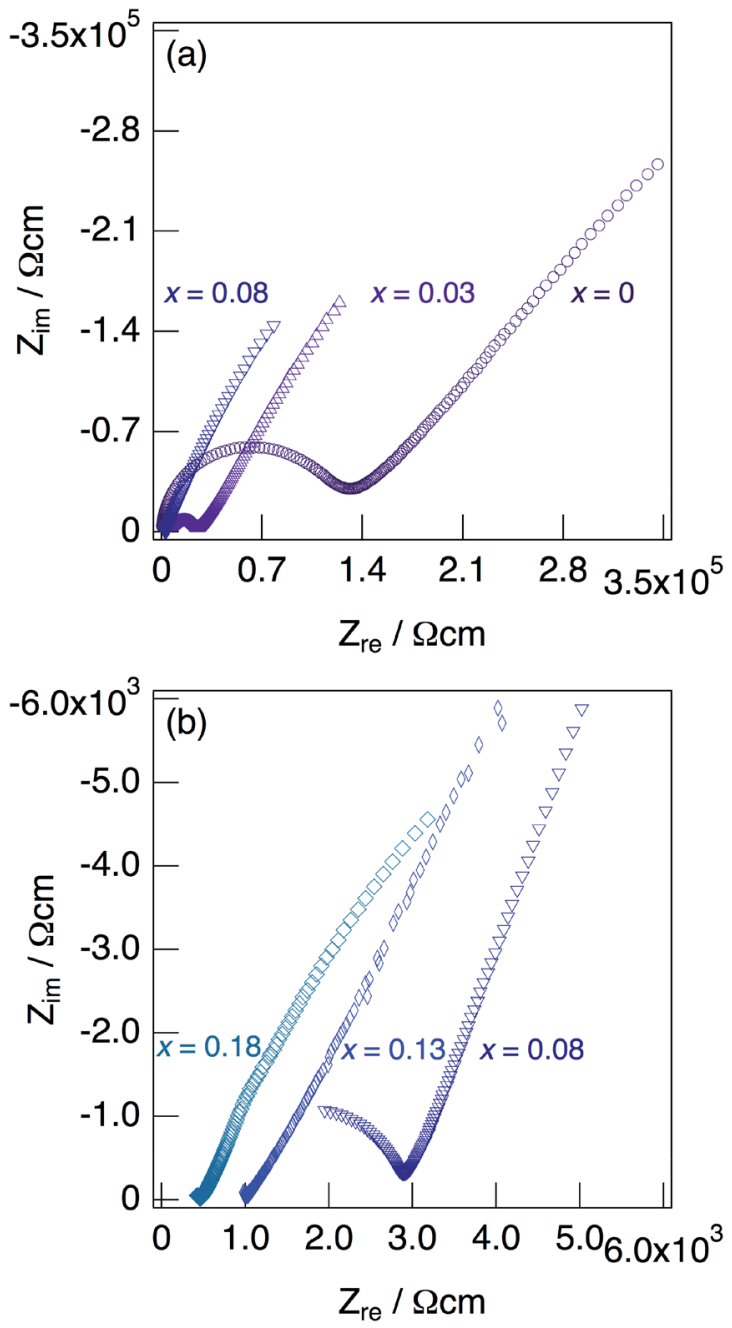

Fig. 7 Impedance plots for $\mathrm{KMg}_{1-x} \mathrm{H}_{2 x}\left(\mathrm{PO}_{3}\right)_{3} \cdot y \mathrm{H}_{2} \mathrm{O}$ with $x=0-0.08$ (a) and $x=0.08-0.18$ (b) measured under $\mathrm{N}_{2}$ gas atmosphere in the closed cell at $150{ }^{\circ} \mathrm{C}$.

sample with $x=0.18$ measured in the closed cell and under a dry Ar gas flow is shown in Fig. S1. $\dagger$ The bulk and total conductivities measured in the dry Ar gas flow were lower than the total conductivity measured in the closed cell in the temperature range of $25-125^{\circ} \mathrm{C}$. The change in the conductivity with respect to humidity in the measurement atmosphere is a typical feature of proton conductors. Fig. 10 shows the temperature dependence of the bulk conductivity for $\mathrm{KMg}_{1-x^{-}}$ $\mathrm{H}_{2 x}\left(\mathrm{PO}_{3}\right)_{3} \cdot y \mathrm{H}_{2} \mathrm{O}$ in a dry Ar gas flow. The sample with $x=0.18$ exhibited higher proton conductivity than the sample with $x=$ 0 in the measured temperature range. The sample with $x=0.18$ in $\mathrm{KMg}_{1-x} \mathrm{H}_{2 x}\left(\mathrm{PO}_{3}\right)_{3} \cdot y \mathrm{H}_{2} \mathrm{O}$ exhibited high proton conductivities of $4.5 \times 10^{-3} \mathrm{~S} \mathrm{~cm}^{-1}$ at $150{ }^{\circ} \mathrm{C}$ and $7.0 \times 10^{-3} \mathrm{~S} \mathrm{~cm}^{-1}$ at $200{ }^{\circ} \mathrm{C}$. The apparent activation energy in the range of 25 to $150^{\circ} \mathrm{C}$ was $0.21 \mathrm{eV}$. The change of the slope from $150^{\circ} \mathrm{C}$ and slight drop of the conductivity above $200^{\circ} \mathrm{C}$ for $\mathrm{KMg}_{1-x} \mathrm{H}_{2 x}\left(\mathrm{PO}_{3}\right)_{3} \cdot y \mathrm{H}_{2} \mathrm{O}$ with $x$ $=0.18$ are attributed to the loss of water of crystallization corresponding to the second dehydration step, which indicates the contribution of coordination water for the proton conduction in 

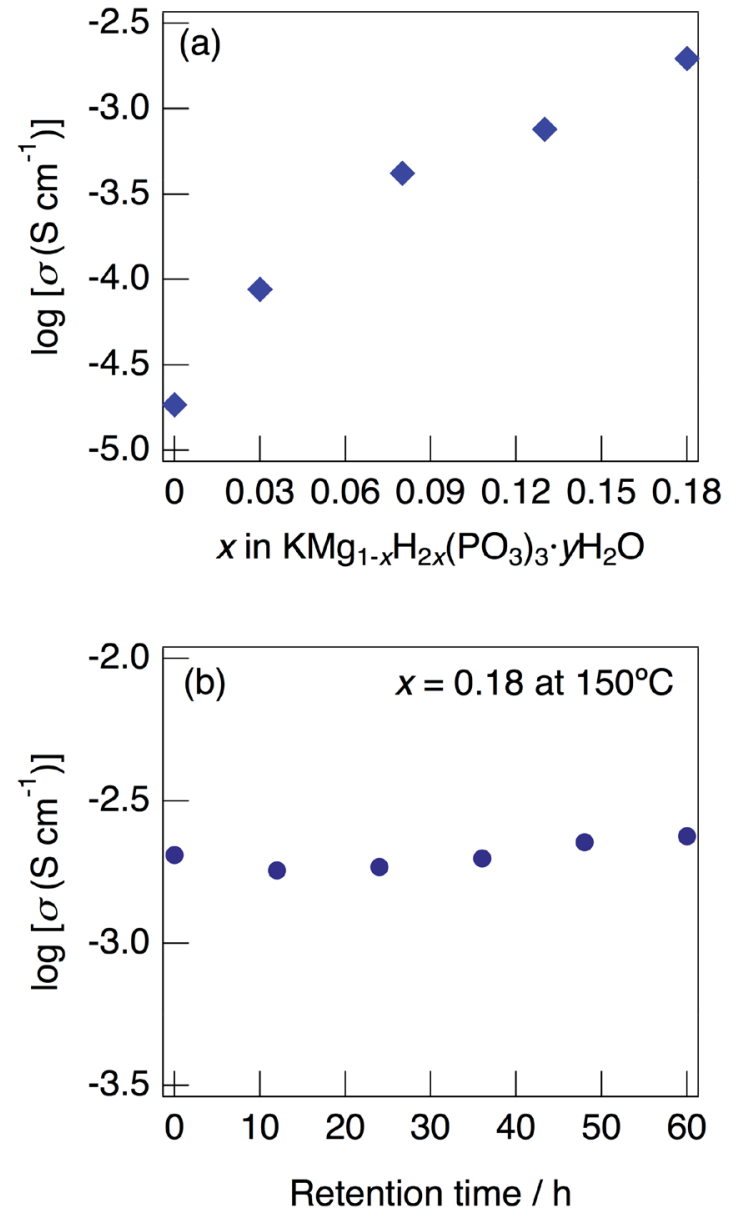

Fig. 8 Variation of total conductivity as a function of $x$ in $\mathrm{KMg}_{1-x^{-}}$ $\mathrm{H}_{2 x}\left(\mathrm{PO}_{3}\right)_{3} \cdot y \mathrm{H}_{2} \mathrm{O}(\mathrm{a})$, and time dependence of the total conductivity of the sample with $x=0.18$ (b) measured at $150{ }^{\circ} \mathrm{C}$ under $\mathrm{N}_{2}$ gas atmosphere in the closed cell.

this temperature range. Since the high bulk conductivity was observed above $150{ }^{\circ} \mathrm{C}$ at which desorption of the adsorbed water was completed, the proton conductivity of this material must be caused by the proton diffusion in the crystal structure.

$\mathrm{KMg}_{1-x} \mathrm{H}_{2 x}\left(\mathrm{PO}_{3}\right)_{3} \cdot y \mathrm{H}_{2} \mathrm{O}$ is the second tunnel phosphate that exhibits fast proton conductivity. The discovery of this material suggests that tunnel framework has tolerance for constituent cations. The combination of $\mathrm{K}^{+}$and $\mathrm{Mg}^{2+}$ results the ordering of cations and the formation of the octahedral chain seen in Fig. 6(b). The combination of cations with the different valences and ionic radii should be one of the keys for the formation of the tunnel framework, because the $\mathrm{PO}_{4}$ tetrahedral chain is formed along the octahedral chain. The replacement of $\mathrm{Rb}^{+}$ with $\mathrm{K}^{+}$changed in the space group of the unit cell with the shift of $\mathrm{K}^{+}$to the off-centered position at the octahedral sites. Since the distance between $\mathrm{K}^{+}$and $\mathrm{O}(3)$, which is the part of oxygen that form $\mathrm{KO}_{6}$ octahedron, is extended, $\mathrm{K}^{+}$coordinates with the oxygen $\mathrm{O}(5)$ of the water molecule for stabilization. $\mathrm{KO}_{6}$ octahedron is connected to the unit composed of three $\mathrm{PO}_{4}$ tetrahedra by corner sharing of $\mathrm{O}(1)$, and $\mathrm{MgO}_{6}$ octahedron is connected to the unit composed of two $\mathrm{PO}_{4}$ tetrahedra. These
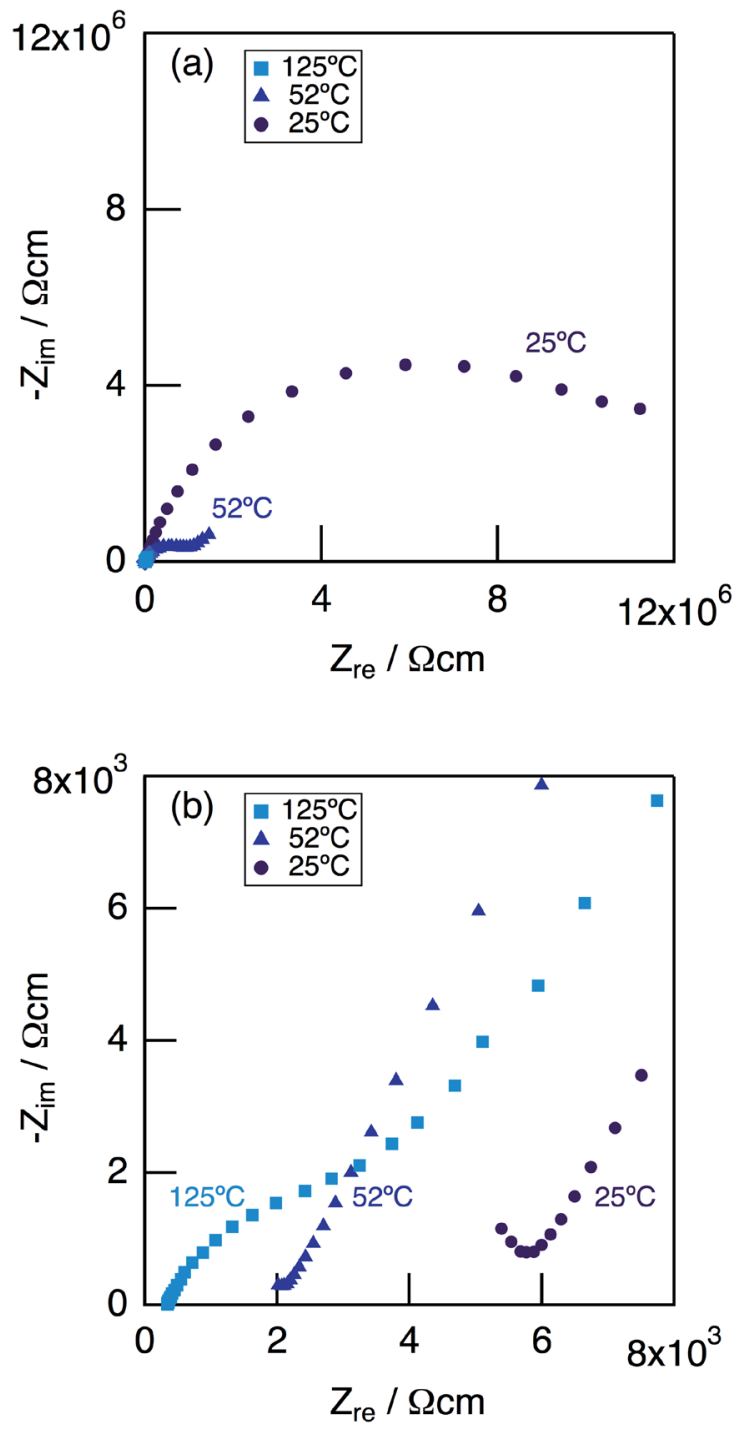

Fig. 9 Impedance plots for $\mathrm{KMg}_{1-x} \mathrm{H}_{2 x}\left(\mathrm{PO}_{3}\right)_{3} \cdot y \mathrm{H}_{2} \mathrm{O}$ with $x=0.18$ measured in a dry $\mathrm{Ar}$ gas flow at $25-125{ }^{\circ} \mathrm{C}$ (a), and expansion of the high frequency part (b).

$\mathrm{PO}_{4}$ tetrahedral units can be adjusted in length in the $z$-axis direction by changing the bond angle of $\mathrm{P}-\mathrm{O}(1)-\mathrm{P}$ for the replacement of alkali cation.

The shrinkage of the framework by the replacement of $\mathrm{Rb}^{+}$ with $\mathrm{K}^{+}$causes two oxygen sites of water molecules in the tunnel. These water molecules exist adjacent to each other in the tunnel due to the connection to $\mathrm{PO}_{4}$ tetrahedral chain through protons. The distance between oxygen in water molecules adjacent in the $c$-axis direction is $1.58 \AA$, and that between those adjacent in the diagonally upward direction is $2.31 \AA$ in $\mathrm{KMg}_{1-x} \mathrm{H}_{2 x}\left(\mathrm{PO}_{3}\right)_{3} \cdot y \mathrm{H}_{2} \mathrm{O}$. In $\mathrm{RbMg}_{1-x} \mathrm{H}_{2 x}\left(\mathrm{PO}_{3}\right)_{3} \cdot y \mathrm{H}_{2} \mathrm{O}$, crystallographically equivalent water molecules form chains. ${ }^{17}$ The distance between oxygen in adjacent water molecules in the $a b$ plane is $1.80 \AA$, and that of water molecules adjacent each other in the $c$-direction is $2.38 \AA$. Due to the shrinkage of the lattice, the distances between water molecules is slightly shortened. 


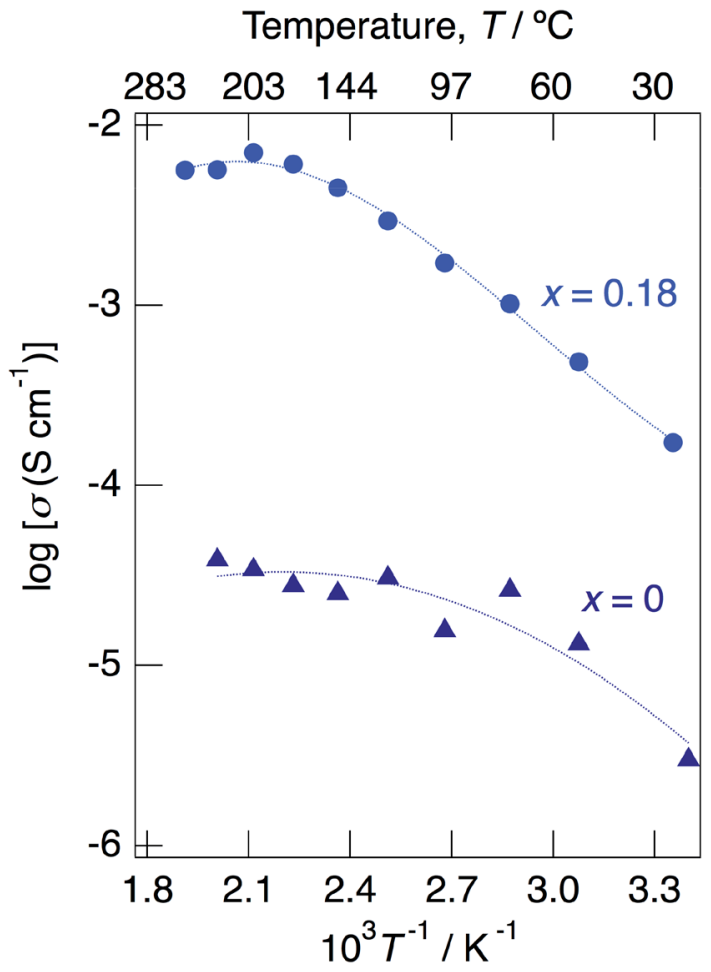

Fig. 10 Temperature dependence of the bulk conductivity for $\mathrm{KMg}_{1-x} \mathrm{H}_{2 x}\left(\mathrm{PO}_{3}\right)_{3} \cdot y \mathrm{H}_{2} \mathrm{O}$ with $x=0$ and 0.18 in a dry Ar gas flow.

In $\mathrm{KMg}_{1-x} \mathrm{H}_{2 x}\left(\mathrm{PO}_{3}\right)_{3} \cdot y \mathrm{H}_{2} \mathrm{O}$, the distance of oxygen sites of water molecules is too short to occupy the adjacent $\mathrm{O}(4)$ and $\mathrm{O}(5)$ sites simultaneously. Therefore, this structural restriction would cause the cooperative movement of water molecules due to electrostatic repulsion force between these molecules above a water content of $1 \mathrm{H}_{2} \mathrm{O}$ per unit formula. In case the water content of $\mathrm{KMg}_{1-x} \mathrm{H}_{2 x}\left(\mathrm{PO}_{3}\right)_{3} \cdot y \mathrm{H}_{2} \mathrm{O}$ is less than the maximum value of water molecules allowed by the structural restriction, which is half of the oxygen sites of water molecules, proton diffusion associated with the hopping of water molecules should be necessary. The structural refinement result suggests that the water content calculated from occupancy values of $\mathrm{O}(4)$ and $\mathrm{O}(5)$ is $1.7 \mathrm{H}_{2} \mathrm{O}$ per unit formula, which is less than $1 / 3$ of all oxygen sites in the tunnel. Therefore, the distribution of water molecules would be suitable for the hopping of water molecules because it resembles the arrangement of mobile cations in other fast ionic conductors. ${ }^{24-27}$ Water molecules would be promoted, so as to be pushed out by the interaction between water molecules. Excess protons introduced at $\mathrm{H}(2)$ and $\mathrm{H}(3)$ sites become carriers and would diffuse in association with water molecules as $\mathrm{H}_{3} \mathrm{O}^{+}$in the tunnel due to the vehicle mechanism. ${ }^{17}$ Further investigations, such as structural studies by the maximum entropy method at different temperatures and nuclear magnetic resonance spectroscopy studies, should provide clear evidence of the proton conduction mechanism.

$\mathrm{KMg}_{1-x} \mathrm{H}_{2 x}\left(\mathrm{PO}_{3}\right)_{3} \cdot y \mathrm{H}_{2} \mathrm{O}$ exhibits high proton conductivity, which is almost comparable to that of $\mathrm{RbMg}_{1-x} \mathrm{H}_{2 x}\left(\mathrm{PO}_{3}\right)_{3^{-}}$ $\cdot y \mathrm{H}_{2} \mathrm{O},{ }^{17}$ over a wide temperature range. It is thought that the formation of water chains has more influence on the proton conductivity rather than the change of the local arrangement between water molecules in the tunnel phosphates. The proton conductivity of $\mathrm{KMg}_{1-x} \mathrm{H}_{2 x}\left(\mathrm{PO}_{3}\right)_{3} \cdot y \mathrm{H}_{2} \mathrm{O}$ showed a positive tendency for the introduction of excess protons. The samples with the composition above $x=0.18$ in $\mathrm{KMg}_{1-x} \mathrm{H}_{2 x}\left(\mathrm{PO}_{3}\right)_{3} \cdot y \mathrm{H}_{2} \mathrm{O}$ is expected to exhibit higher proton conductivity, however crystalline samples with these compositions were not obtained in present study.

$\mathrm{KMg}_{1-x} \mathrm{H}_{2 x}\left(\mathrm{PO}_{3}\right)_{3} \cdot y \mathrm{H}_{2} \mathrm{O}$ is composed of inexpensive and abundant elements and exhibits a high proton conductivity above $10^{-3} \mathrm{~S} \mathrm{~m}^{-1}$ at $150{ }^{\circ} \mathrm{C}$ for long periods, which are preferable for proton solid electrolyte applications. Solid acids such as $\mathrm{CsHSO}^{4}$ and $\mathrm{CsH}_{2} \mathrm{PO}_{4}$ exhibit high proton conductivity due to the proton diffusion via rotation and rearrangement of poly-anions above the phase transition temperature. ${ }^{28}$ Since the structure of the high temperature phase formed by hydrogen bonds is thermally unstable, the temperature range at which these solid acids exhibit high proton conductivity is restricted. In contrast to these solid acids, $\mathrm{KMg}_{1-x} \mathrm{H}_{2 x}\left(\mathrm{PO}_{3}\right)_{3} \cdot y \mathrm{H}_{2} \mathrm{O}$ exhibits high proton conductivity at low temperature, because the proton diffusion pathway of water chains exists in the tunnel at room temperature. The rigid framework of $\mathrm{KMg}_{1-x} \mathrm{H}_{2 x}\left(\mathrm{PO}_{3}\right)_{3} \cdot y \mathrm{H}_{2} \mathrm{O}$ is an advantage for the improvement of the thermal stability, however the retention of the water of crystallization is an issue to expand the operation temperature of water-contained proton conductors at high temperature. $\mathrm{KMg}_{1-x} \mathrm{H}_{2 x}\left(\mathrm{PO}_{3}\right)_{3} \cdot y \mathrm{H}_{2} \mathrm{O}$ exhibits high proton conductivity of $7.0 \times 10^{-3} \mathrm{~S} \mathrm{~cm}^{-1}$ at $200{ }^{\circ} \mathrm{C}$ at which other proton conductors that contain water molecules become unstable. ${ }^{29-31}$ The coincidence between the water content calculated from the weight loss at the second dehydration step observed in the TG curve and that obtained from the occupancy value of $\mathrm{O}(5)$ suggests that water molecules coordinated to $\mathrm{K}^{+}$are retained at high temperatures. It suggests that the electrostatic bonding between cation and oxygen of water molecules is much stronger than the connection of water molecules via hydrogen bonds. The connection of water molecules to $\mathrm{PO}_{4}$ tetrahedral chains via hydrogen bonds contributes to the formation of water chains that are proton diffusion pathway, whereas the coordination of water molecules to large cation of $\mathrm{K}^{+}$in the face-shared octahedral chains is important for the retention of water molecules in the tunnel structure at high temperatures. The strong bonding of the coordination water is considered to be disadvantageous for the fast proton diffusion, however the formation of the water chain which is suitable for the proton diffusion associated with the jump of water molecules compensates for this disadvantage and causes high proton conductivity in the tunnel phosphate. Structural study in present study suggests that the material design by utilizing the connection of oxygen of water molecules to cation in the rigid framework, which is overlooked at the material design focusing on the hydrogen bonds, has a potential to overcome the thermal instability of proton conductors. $\mathrm{KMg}_{1-x} \mathrm{H}_{2 x}\left(\mathrm{PO}_{3}\right)_{3} \cdot y \mathrm{H}_{2} \mathrm{O}$ shows that tunnel phosphates are promising as fast proton conductors, and tolerance for constituent cations of the tunnel framework suggests that other isostructural compounds could be derived. Further investigation of tunnel phosphates with unique water chains is believed to provide proton solid electrolytes that 
exhibit higher proton conductivity in over a wide temperature range.

\section{Conclusions}

A new proton conductor, $\mathrm{KMg}_{1-x} \mathrm{H}_{2 x}\left(\mathrm{PO}_{3}\right)_{3} \cdot y \mathrm{H}_{2} \mathrm{O}$, was synthesized by the coprecipitation method. $\mathrm{KMg}_{1-x} \mathrm{H}_{2 x}\left(\mathrm{PO}_{3}\right)_{3} \cdot y \mathrm{H}_{2} \mathrm{O}$ formed a solid solution between $x=0$ and $x=0.18$. The dehydration of $\mathrm{KMg}_{1-x} \mathrm{H}_{2 x}\left(\mathrm{PO}_{3}\right)_{3} \cdot y \mathrm{H}_{2} \mathrm{O}$ occurred at $30{ }^{\circ} \mathrm{C}$ and $150{ }^{\circ} \mathrm{C}$, which reflects different coordination environments of the waters of crystallization. $\mathrm{KMg}_{1-x} \mathrm{H}_{2 x}\left(\mathrm{PO}_{3}\right)_{3} \cdot y \mathrm{H}_{2} \mathrm{O}$ formed a tunnel framework composed of $\left(\mathrm{KO}_{6}\right)$ and $\left(\mathrm{MgO}_{6}\right)$ one-dimensional chains, and $\mathrm{PO}_{4}$ tetrahedral chains along the $c$-direction by corner-sharing. Two oxygen sites of water molecules were detected in the onedimensional tunnel, one of which exists as a coordination water of $\mathrm{K}^{+}$sites. Water molecules are connected to $\mathrm{PO}_{4}$ tetrahedra by hydrogen bonds and form a chain along the $c$-axis in the tunnel. The $\mathrm{KMg}_{1-x} \mathrm{H}_{2 x}\left(\mathrm{PO}_{3}\right)_{3} \cdot y \mathrm{H}_{2} \mathrm{O}$ sample with $x=0.18$ exhibited high proton conductivities of $4.5 \times 10^{-3} \mathrm{~S} \mathrm{~cm}^{-1}$ at $150{ }^{\circ} \mathrm{C}$ and $7.0 \times 10^{-3} \mathrm{~S} \mathrm{~cm}^{-1}$ at $200{ }^{\circ} \mathrm{C}$ in a dry $\mathrm{Ar}$ gas flow and maintained the total conductivity above $10^{-3} \mathrm{~S} \mathrm{~cm}^{-1}$ for $60 \mathrm{~h}$ at $150{ }^{\circ} \mathrm{C}$ under $\mathrm{N}_{2}$ gas atmosphere.

\section{Conflicts of interest}

There are no conflicts to declare.

\section{Acknowledgements}

This work was partly supported by the Nanotechnology Platform Program (Molecule and Material Synthesis) of the Ministry of Education, Culture, Sports, Science and Technology (MEXT), Japan. The neutron scattering experiment was approved by the Neutron Scattering Program Advisory Committee of the Institute of Materials Structure Science, High Energy Accelerator Research Organization (2014S10). The authors are deeply grateful to Prof. Yasuo Takeda of Mie University for advice on the discussion given in the paper. This work was supported by JSPS KAKENHI Grant Number 19H05793 for DM.

\section{References}

1 H. Luecke, B. Schobert, H. T. Richter, J. P. Cartailler and J. K. Lanyi, Structural Changes in Bacteriorhodopsin During Ion Transport at 2 Angstrom Resolution, Science, 1999, 286, 255-260.

2 S. Iwata, C. Ostermeier, B. Ludwig and H. Michel, Structure at $2.8 \AA$ resolution of cytochrome $c$ oxidase from Paracoccus denitrificans, Nature, 1995, 376, 660-669.

$3 \mathrm{~W}$. Gu and V. Helms, Tightly Connected Water Wires Facilitate Fast Proton Uptake at the Proton Entrance of Proton Pumping Proteins, J. Am. Chem. Soc., 2009, 131, 2080-2081.

4 S. M. Haile, D. A. Boysen, C. R. I. Chisholm and R. B. Merle, Solid acids as fuel cell electrolytes, Nature, 2001, 410, 910913.
5 D. A. Boysen, T. Uda, C. R. I. Chisholm and S. M. Haile, HighPerformance Solid Acid Fuel Cells Through Humidity Stabilization, Science, 2004, 303, 68-70.

6 M. Inukai, S. Horike, T. Itakura, R. Shinozaki, N. Ogiwara, D. Umeyama, S. Nagarkar, Y. Nishiyama, M. Malon, A. Hayashi, T. Ohhara, R. Kiyanagi and S. Kitagawa, Encapsulating Mobile Proton Carriers into Structural Defects in Coordination Polymer Crystals: High Anhydrous Proton Conduction and Fuel Cell Application, J. Am. Chem. Soc., 2016, 138, 8505-8511.

7 R. Haugsrud and T. Norby, Proton conduction in rare-earth ortho-niobates and ortho-tantalates, Nat. Mater., 2006, 5, 193-196.

8 C. Sun, L. Chen, S. Siqi, B. Reeb, C. A. López, J. A. Alonso and U. Stimming, Visualization of the Diffusion Pathway of Protons in $\left(\mathrm{NH}_{4}\right)_{2} \mathrm{Si}_{0.5} \mathrm{Ti}_{0.5} \mathrm{P}_{4} \mathrm{O}_{13}$ as an Electrolyte for Intermediate-Temperature Fuel Cells, Inorg. Chem., 2018, 57, 676-680.

9 T. Norby, Solid-state protonic conductors: principles, properties, progress and prospects, J. Solid State Chem., 1999, 125, 1-11.

10 M. G. Shilton and A. T. Howe, Rapid $\mathrm{H}^{+}$conductivity in hydrogen uranyl phosphate-A solid $\mathrm{H}^{+}$electrolyte, Mater. Res. Bull., 1977, 12, 701-706.

11 A. T. Howe and M. G. Shilton, Studies of layered uranium (VI) compounds. I. High proton conductivity in polycrystalline hydrogen uranyl phosphate tetrahydrate, $J$. Solid State Chem., 1979, 28, 345-361.

$12 \mathrm{M}$. Casciola and D. Bianchi, Frequency response of polycrystalline samples of $\alpha-\mathrm{Zr}\left(\mathrm{HPO}_{4}\right)_{2} \cdot \mathrm{H}_{2} \mathrm{O}$ at different relative humidities, Solid State Ionics, 1985, 17, 287-293.

13 A. I. Baranov, L. A. Shuvalov and N. M. Schagina, Superion conductivity and phase transitions in $\mathrm{CsHSO}_{4}$ and $\mathrm{CsHSeO}_{4}$ crystals, JETP Lett., 1982, 36, 459-462.

14 E. A. Ulkshe, L. S. Leonova and A. I. Korosteleva, Protonic conduction in heteropoly compounds, Solid State Ionics, 1989, 36, 219-223.

15 H. Iwahara, T. Esaka, H. Uchida and N. Maeda, Proton conduction in sintered oxides and its application to steam electrolysis for hydrogen production, Solid State Ionics, 1981, 3-4, 359-363.

16 R. B. Cervera, S. Miyoshi, Y. Oyama, Y. E. Elammari, T. Yagi and S. Yamaguchi, Perovskite-Structured $\mathrm{BaScO}_{2}(\mathrm{OH})$ as a Novel Proton Conductor: Heavily Hydrated Phase Obtained via Low-Temperature Synthesis, Chem. Mater., 2013, 25, 1483-1489.

17 Y. Matsuda, M. Yonemura, H. Koga, C. Pitteloud, M. Nagao, M. Hirayama and R. Kanno, Synthesis, crystal structure, and ionic conductivity of tunnel structure phosphates, $\mathrm{RbMg}_{1-\mathrm{x}} \mathrm{H}_{2 \mathrm{x}}\left(\mathrm{PO}_{3}\right)_{3} \cdot \mathrm{y}\left(\mathrm{H}_{2} \mathrm{O}\right)$, J. Mater. Chem. A, 2013, 1, 15544-15551.

18 F. Izumi and K. Momma, Three-dimensional Visualization in Powder Diffraction, Solid State Phenom., 2007, 130, 15-20.

19 R. Oishi, M. Yonemura, Y. Nishimaki, S. Torii, A. Hoshikawa, T. Ishigaki, T. Morishima, K. Mori and T. Kamiyama, Rietveld analysis software for J-PARC, Nucl. Instrum. Methods Phys. Res., Sect. A, 2009, 600, 94-96. 
20 R. Masse, J. C. Grenier, M. T. Averbuch-Pouchol, T. Q. Duc and A. Durif, Crystallographic study of hexagonal trimetaphosphates of the type $\mathrm{MiNH}_{4}\left(\mathrm{PO}_{3}\right)_{4}$ ( $\mathrm{Mii}=$ zinc, cobalt, calcium, cadmium, magnesium, manganese). $\mathrm{P}_{3} \mathrm{O}_{9}$ ring in an isomorphous Potassium salt- $\mathrm{MgK}\left(\mathrm{PO}_{3}\right)_{3}$, Bull. Soc. Fr. Mineral. Cristallogr., 1967, 90, 158-161.

21 A. A. Kapshuk, P. G. Nagornyi and O. V. Petrenko, Synthesis, IR spectra, and structures of double metaphosphates $\mathrm{MNi}\left(\mathrm{PO}_{3}\right)_{3}(\mathrm{M}=\mathrm{Na}$ or $\mathrm{K})$, Kristallografiya, 2000, 45, 238-241.

22 J. M. Troup and A. Clearfield, Mechanism of ion exchange in zirconium phosphates. 20. Refinement of the crystal structure of alpha.-zirconium phosphate, Inorg. Chem., 1977, 16, 3311-3313.

23 M. Arefian, M. Mirzaei and H. Eshtiagh-Hosseini, Structural insights into two inorganic-organic hybrids based on chiral amino acids and polyoxomolybdates, J. Mol. Struct., 2017, 1156, 550-558.

24 N. Kamaya, K. Homma, Y. Yamakawa, M. Hirayama, R. Kanno, M. Yonemura, T. Kamiyama, Y. Kato, S. Hama, K. Kawamoto and A. Mitsui, A lithium superionic conductor, Nat. Mater., 2011, 10, 682-686.

25 O. Kwon, M. Hirayama, K. Suzuki, Y. Kato, T. Saito, M. Yonemura, T. Kamiyama and R. Kanno, Synthesis, structure, and conduction mechanism of the lithium superionic conductor $\mathrm{Li}_{10+\delta} \mathrm{Ge}_{1+\delta} \mathrm{P}_{2-\delta} \mathrm{S}_{12}$, J. Mater. Chem. A, 2015, 3, 438-446.
26 Y. Matsuda, Y. Itami, K. Hayamizu, T. Ishigaki, M. Matsui, Y. Takeda, O. Yamamoto and N. Imanishi, Phase relation, structure and ionic conductivity of $\mathrm{Li}_{7-\mathrm{x}-3 \mathrm{y}} \mathrm{AlyLa}_{3} \mathrm{Zr}_{2-\mathrm{x}} \mathrm{Ta}_{\mathrm{x}} \mathrm{O}_{12}$, RSC Adv., 2016, 6, 78210-78218.

27 J. Awaka, A. Takashima, K. Kataoka, N. Kijima, Y. Idemoto and J. Akimoto, Crystal Structure of Fast Lithium-ionconducting Cubic $\mathrm{Li}_{7} \mathrm{La}_{3} \mathrm{Zr}_{2} \mathrm{O}_{12}$, Chem. Lett., 2011, 40, 60-62.

$28 \mathrm{~V}$. Ponomareva and G. Lavrova, Controlling the proton transport properties of solid acids via structural and microstructural modification, J. Solid State Electrochem., 2011, 15(2), 213-221.

29 M. Casciola and U. Costantino, Relative humidity influence on proton conduction of hydrated pellicular zirconium phosphate in hydrogen form, Solid State Ionics, 1986, 20, 69-73.

30 S. D. Courant, Y. Piffard, P. Barboux and J. Livage, Relative humidity influence on the water content and on the protonic conductivity of the phosphatoantimonic acids $\mathrm{HnSbnP}_{2} \mathrm{O}_{3 \mathrm{n}+5}, \mathrm{xH}_{2} \mathrm{O}(\mathrm{n}=1,3,5)$, Solid State Ionics, 1988, 27, 189-194.

31 A. Hardwick and P. G. Dickens, Investigation of $\mathrm{H}^{+}$motion in the 21-hydrates of 12-tungstophosphoric and 12molybdophosphoric acids by ac conductivity and pulsed ${ }^{1}$ H NMR measurements, Solid State Ionics, 1984, 13, 345-350. 